\title{
Retraction Note to: Various articles by R.-L. Etienne Barnett in Neohelicon
}

\author{
R.-L. Etienne Barnett
}

Published online: 23 January 2015

(C) Akadémiai Kiadó, Budapest, Hungary 2015

\author{
Retraction to: Neohelicon \\ DOI 10.1007/s11059-008-3007-9, \\ DOI 10.1007/s11059-008-4013-7, \\ DOI 10.1007/s11059-009-1015-z, \\ DOI 10.1007/s11059-010-0065-6, \\ DOI 10.1007/s11059-010-0081-6, \\ DOI 10.1007/s11059-011-0111-z, \\ DOI 10.1007/s11059-012-0120-6, \\ DOI 10.1007/s11059-013-0186-9, \\ DOI 10.1007/s11059-013-0210-0, \\ DOI 10.1007/s11059-013-0232-7, \\ DOI 10.1007/s11059-006-0032-4, \\ DOI 10.1007/s11059-007-1013-y and \\ DOI 10.1007/s11059-014-0235-z
}

Careful analysis of the below mentioned articles by R.-L. Etienne Barnett, published in Neohelicon, has led me to the conclusion that these contributions show extensive

\footnotetext{
The online version of these original articles correspondingly to the above be found under doi $10.1007 /$ s11059-008-3007-9; 10.1007/s11059-008-4013-7; 10.1007/s11059-009-1015-z; 10.1007/s11059-0100065-6; 10.1007/s11059-010-0081-6; 10.1007/s11059-011-0111-z; 10.1007/s11059-012-0120-6; 10. 1007/s11059-013-0186-9; 10.1007/s11059-013-0210-0; 10.1007/s11059-013-0232-7; 10.1007/s11059006-0032-4; 10.1007/s11059-007-1013-y; 10.1007/s11059-014-0235-z.
}

\section{R.-L. E. Barnett $(\bowtie)$}

Office of the University Provost, Dean of Faculty and Frederick A. Treuhaft Foundation, Distinguished Professor, University of Atlanta, Atlanta, GA 30360, USA

e-mail: RL_Barnett@msn.com; RLEBarnett@cnrsparis.eu

R.-L. E. Barnett

Centre National de la Recherche Scientifique, rue de Rivoli, 75005 Paris, France 
similarities with earlier publications, by others and by Barnett himself; see the list printed below for details. This constitutes a series of cases of plagiarism and selfplagiarism which go against the publication policy of the journal Neohelicon, its publisher Akadémiai Kiadó, and Springer. For this reason the articles in question have been retracted. I offer my sincere apologies to the authors of the original publications and to the readers that this was not detected during the submission and review process.

Péter Hajdu, Editor-in-Chief, for the Editorial Committee of Neohelicon

1. The article entitled "Sur l'émiettement chaotique du sens" published in Neohelicon in 2008, Vol. 35, No. 1, pp. 97-105, 2008) shows extensive similarities with chapter VII of the book Mosaïques, by Lucien Dällenbach, published by Seuil in 1999, p. 115 s.

2. The article entitled "Les enjeux de la parole" published in Neohelicon in 2008, Vol. 35, No. 2, pp. 181-189, 2008) shows extensive similarities with the article published by Jean-Pierre Martin, "Le critique et la voix", Etudes françaises, Vol. 39, no.1, pp. 13-23, 2003.

3. The article entitled "The semiotics of 'transit' in Joyce's Ulysses", published in Neohelicon in 2009, Vol. 36, No. 1, pp. 153-166, 2009) shows extensive similarities with the article published by Eric P. Levy, "The Mimesis of Metempshychosis" in Ulysses, Philological Quarterly, Vol. 81, no.3, pp. 359-377, 2002.

4. The article entitled "Autopsies du centre" published in Neohelicon in 2010, Vol. 37, No. 2, pp. 479-487, 2010) shows extensive similarities with the article published by Jan Baetens, "Fausses marges et vraie marginalité", L'Esprit Créateur, Vol. 38, no.1, pp. 69-78, 1998.

5. The article entitled "Apories cioraniennes," published in Neohelicon in 2011 (Vol. 38, No. 1, pp. 177-185, 2011) shows extensive similarities with the article published by Pierre Nepveu, "Cioran ou la maladie de l'éternité", Etudes Françaises, Vol. 37, no.1, pp. 11-21, 2001.

6. The article entitled "Les épreuves du labyrinthe rochien," published in Neohelicon in 2011 (Vol. 38, No.2, pp. 457-464, 2011) shows extensive similarities with the article published by Stéphane Baquey, "Denis Roche, la rage de 1'expression", Prétexte No. 21-22, pp. 23-29, 1999.

7. The article entitled "Absence et subterfuge modianesques," published in Neohelicon in 2012 (Vol. 39, No. 1, pp. 73-87, 2012) shows extensive similarities with the article published by Paul Raymond Côté, "Ellipse et réduplication", Romanic Review Vol. 85, No. 1, pp. 143-156, 1994.

8. The article entitled "Aux alentours du néant: propos sur l'anodin," published in Neohelicon in 2013 (Vol. 40, No. 1, pp. 99-114, 2013) shows extensive similarities with the article published by Jacques Poirier, "Malaise dans la signification", Etudes françaises, Vol. 45, No. 1, pp. 109-124, 2009.

9. The article entitled "Paroles disloquées," published in Neohelicon in 2013 (Vol. 40, No. 2, pp. 509-520, 2013) shows extensive similarities with the article published by Laurent Demanze, "Les possédés et les dépossédés", Etudes françaises, Vol. 45, No. 3, pp. 11-23, 2009. 
10. The article entitled "Paroles à la dérive," published in Neohelicon in 2014 (Vol. 41, No. 1, pp. 129-143, 2014). shows extensive similarities with the article published by René Audet, "Lieux et pragmatique de la monstruosité dans la prose narrative d'Eric Chevillard", Tangence, Vol. 91, Automne, pp. 11-27, 2009.

Self-plagiarism by Etienne Barnett as discovered;

11. The article entitled "La parole monstrueuse" published in Neohelicon in 2006 (Vol. 33, No. 2, pp. 165-178, 2006) shows extensive similarities with the article "Herméneutique et indicible raciniens: re-lecture". Dalhousie French Studies, Vol. 44, Fall 1998, pp. 13-22.

12. The article entitled "Of difference contrived: The semiotics of sameness in J.-K. Huysmans' a rebours" published in Neohelicon in 2007 (Vol. 34, No. 1, pp. 137-143, 2007) shows extensive similarities with the article "Of infinite regress: paradigms unbroken in J.-K. Huysmans's a rebours" Revista Letras, 1999, Vol. 52.

Online First, recently published article by Etienne Barnett as discovered;

13. The article entitled "Désignifier au pluriel" published 'online first' in Neohelicon in 2014 shows extensive similarities with the article published by Audrey Camus, "Les contrées étranges de l'insignifiant, Retour sur la notion de fantastique moderne", Etudes françaises, Vol. 45, No. 1, pp. 89-107, 2009 (http://www.erudit.org/revue/ETUDFR/2009/v45/n1/029841ar.html). 